\title{
Issues Salience and Framing in the Taiwanese 2016 Presidential Election Campaign: An Analysis of the KMT and DPP Campaign Discourses
}

\author{
Lutgard Lams
}

Associate Professor, Faculty of Arts, KU Leuven, Brussels, Belgium lut.lams@kuleuven.be

\begin{abstract}
This paper aims to provide insights into electoral practices of agenda setting and issue framing in the Taiwanese 2016 presidential election campaign. It examines issue salience and discursive mechanisms, like causal projection patterns, used in constructing problem definitions. The study unravels the securitisation narrative by showing how separate issues are collated into coherent packages and explores how key phrases, such as 'status quo' and '1992 Consensus' are conceptualised. The analysis also investigates discursive ambiguities, since the DPP candidate's campaign style was criticised for being vague. Units of analysis are English-language texts, taken from the кмт and DPP candidates' speeches and their media opinion articles, targeting the foreign community, and translated versions of Chinese-language campaign materials, designed for the Taiwanese population. Comparison shows a two-level communicative game in audience differentiation, but the mechanism of guiding people not only what to think about, but also what to think, applies irrespective of audience design.
\end{abstract}

\section{Keywords}

Taiwan 2016 presidential elections - KMT and DPP campaign discourses - 1992 Consensus - status quo - issue salience - agenda setting and framing - ambiguity securitisation narrative

\section{Introduction}

A casual glimpse at foreign news coverage of the 2016 Taiwan presidential elections suggests a focus on the security issue in the Taiwan Strait. Phrased in the 
conditional, foreign journalists speculated about increased cross-Strait friction, should the Democratic Progressive Party (DPP) candidate Tsai Ing-wen (蔡英文) win the elections. ${ }^{1}$ Secondly, Tsai's campaign was characterised as altogether vague and ambiguous. While this study does not analyse how the international media covered the elections, it was inspired by reading the international perspective. The author's curiosity was further aroused, when this portrayal resurfaced during postelection interviews conducted with academics and Kuomintang (KMT) and People First Party (PFP) politicians. Similarly, in conversations with Taiwanese citizens about the elections, the metaphorical, but derisive, reference to 'empty spinach,', ${ }^{2}$ depicting Tsai Ing-wen as hollow, emerged again. Hence, this study embarks on an exploratory journey into the salience and clarity of campaign issues and the ways in which they were conceptualised in the original campaign discourses. ${ }^{3}$ What issues determined the agenda and how were the issues, as well as the contenders' campaigning style, framed in order to prime public opinion and steer voter behaviour?

When it comes to discussing Taiwan politics as an academic, a journalist, a politician, or an ordinary citizen, one invariably encounters questions of a discursive or interpretive nature. Lams (2012), for example, presents an in-depth discussion on the various interpretations/definitions of the concepts at stake. Two of these have a renewed relevance for the 2016 election campaign, the meaning of the '1992 Consensus' and the 'status quo' in cross-Strait relations, since both notions constitute the prime locus of interpretative difference between the KMT and the DPP and were widely discussed in the local and foreign media prior to the elections. This begs the question where these issues featured on the agenda of the candidates and how they were interpreted or framed. These questions require a qualitative analysis of presentation and argumentation practices. This is why the present study adopts a discourse-analytical approach in examining issue salience and framing in the 2016 campaign.

The analysis is meant to contribute to existing research about Taiwanese presidential elections, such as the quantitative content analysis of negativity

1 Exceptions can be found, for example, Hsu (2015).

2 The noun phrase 'empty-hearted Tsai' (kongxin cai, 空心蔡) is a homophone with the Taiwanese water spinach vegetable 'kongxin cai' (空心菜).

3 This article is the first instalment of a larger project, investigating both English- and Chineselanguage campaign materials for comparative reasons. While the Chinese-language analysis is still ongoing, the present article focuses entirely on the English-language materials, since the attention to the foreign community already denotes a marked difference in approach and international outreach between the three campaigns. 
in campaign ads (Sullivan, 2009a, 2009b; Sullivan \& Sapir, 2012). ${ }^{4}$ Copper (2003) and Chu (2005) have interpreted negativity as 'an indication of deficits in Taiwan's political culture and the quality of Taiwan's democracy' (Sullivan \& Sapir, 2012: 149). As the Taiwan national and local elections contain a high level of drama, scholarly analyses have often focused on the fierce contests and the negativity involved in such a horse race (Chu, 2005; Copper, 2003; Lams, 2008; Rawnsley, 2003; Sullivan, 2009a, 2009b; Sullivan \& Sapir, 2012). Taiwanese campaigns, as in other countries, are not void of mudslinging, but more specific to the Taiwanese scene, contestants often resort to mutual allegations of vote-buying (Schafferer, 2006). A more positive aspect of Taiwanese electoral culture is its dynamism, resembling 'democratic festivals' (Fell, 2011: 56). Rawnsley (2003) draws a particularly vivid picture of Taiwanese citizen engagement and exhilaration at rallies, which is still the preferred method to mobilise supporters. With telling quotes from the Taiwanese English-language newspaper, Taipei Times, Rawnsley depicts how hospital wards are filled with citizens suffering from election mania disorder (2003: 777). Additional studies have focused on the analysis of campaign rhetoric (Damore, 2002; Fell, 2005; Geer, 2006; Rawnsley, 2003), metaphorical usage of campaign slogans in the 1996 presidential campaign in Taiwan (Wei, 200o), campaign strategies (Clark, 2005; Fell, 2005; Rawnsley, 2003; Sullivan \& Sapir, 2012), or the level of media participation in the electoral campaigns (Chan-Olmstead and Chiu, 1999; Lams, 2008; Rawnsley, 2003, 2005).

While this paper does not examine statistical correlations between specific presidential speeches' content and context of strategic message delivery, such as audience design (Rich \& Sullivan, $2016 \mathrm{Wu}, 2011$ ), it takes audience differentiation into account when analysing the speeches that target Western (especially North American) or domestic audiences. Examining how the campaign messages are constructed for the international community, which is not directly involved in the voting process, is also relevant in a study of agenda setting. Given the precarious cross-Strait condition and Taiwanese reliance on international economic and political support, securing foreign support is an essential part of the electoral game. Foreign elite statements about the campaign are not only indicative of the nature of the future engagement with Taiwan but can also be considered as important psychological drivers in steering domestic voting behaviour. Governments often use a two-level game in their communications. Judging from the thematic priority differences in addressing foreign and local communities, as will be discussed in the first part of the analysis, the

4 For a more extensive survey of the academic literature on Taiwan's elections, see Rich and Sullivan (2016). 
Taiwanese presidential candidates also adopt this two-level communicative game in prioritising different issues depending on the targeted audience. Yet, the mechanism of guiding people in showing 'not only what to think about', but also 'what to think' applies to all texts that were analysed, irrespective of audience design.

\section{Theoretical Perspectives}

To better understand the cognitive processes underlying discourses generated during campaign periods, useful points of entry are agenda setting, priming, and framing theory, often used in communication studies and political communication. While this article does not aim to present a theoretical account in pinpointing the type of priming model ${ }^{5}$ that the candidates employ for maximum priming efficacy, it demonstrates how the mechanisms of agenda setting, priming, and framing operate in the Taiwanese electoral campaign process to influence both domestic and foreign opinion. To achieve this, it examines issue salience and framing through a discourse-analytical approach, as will be explained in the section on research method. The theory of agenda setting, priming, and framing underpins the analysis of both types of sources (campaign speeches and media reports) utilised for this study, since these discursive processes are evident in the context of media construction of reality as well as in politicians' perspectives.

The electoral processes of agenda setting, priming, and framing are commonplace in any election, but in the Taiwan case, these mechanisms targeting a foreign audience are particularly important because the outcome of the elections can have a considerable impact on regional security and stability, implicating the two great powers, China and the United States. The international perspective also matters because the way in which the candidates' priorities in foreign policy, international security, and economic policies involving international trade issues are presented to the international community may influence foreign elite opinion and consequently decisions on future collaboration with the elected presidential team. This explains the great effort presidential candidates have made in addressing the u.s. audience during campaign periods. In addition, any laudatory or critical comment by the international stakeholders about the candidates' proposed platforms is monitored closely in

5 On the theoretical perspectives of the resonance model, considering the relationship between message content and receivers' predispositions, and the strategic model, highlighting the interactions between competing platforms, see Iyengar and Simon (2000). 
Taiwan and can influence voters' behaviour in a psychological reaction based on confidence in continued American support or lack thereof, or fear of Chinese retaliation.

The theory of agenda setting originally relates to the construction of public awareness and concern of salient issues by the news media. It holds that media can determine what the public deems important and finds its origin in the work of Lippmann (1922), who first pointed out the connection between events in the world and mental pictures. It was further developed in the hypothesis by Cohen (1963: 13) that 'the press may not be successful much of the time in telling people what to think, but it is stunningly successful in telling its readers what to think about'. The concept of 'agenda setting' itself was coined by McCombs and Shaw (1972), who provided empirical evidence that salience of issues on the news agenda (by relative placement or amount of coverage) has a high correlation with the importance attributed to these issues by the voters. Agenda-setting theory can thus help illuminate why certain issues are constructed into the public discourse domain (Druckman, Jacobs, \& Ostermeier, 2004). An election campaign is a conversation among the political elite, the media, and the citizens about the future of the nation (Perloff, 1998). This 'transactional process' can be understood as 'exchanges of influences among various agenda-setters' (Min, 2004: 192). Hence, politicians and media alike can set the agenda. The theoretical dimension of 'priming', as identified by lyengar, Peters, and Kinder (1982), is used in a political context and goes beyond agenda setting in that it creates different standards by which the public evaluates political elites through selectively drawing attention to some aspects of politics at the expense of others (Iyengar \& Kinder, 1987). As Scheufele and Tewksbury (2007) put it:

Priming occurs when news content suggests to news audiences that they ought to use specific issues as benchmarks for evaluating the performance of leaders and governments.... By making some issues more salient in people's mind (agenda-setting), mass media can also shape the considerations that people take into account when making judgments about political candidates or issues (priming) (2007:11).

That priming can also be a deliberate process by politicians to steer candidate behaviour is made evident in the study by Jacobs and Shapiro (1994) on John F. Kennedy's 1960 presidential campaign, demonstrating deliberate strategies the candidates pursue to influence voters, such as using public opinion surveys that enable the candidates to position themselves in an optimal way to attract votes. Jacobs and Shapiro draw on the social psychological process of priming 
'to understand the interconnectedness of image and issues in campaign strategy' and argue that 'candidates use popular policy issues to "prime" the electorate's standards for evaluating their personal attributes' (1994: 527).

An electoral candidate can prefer to repeat familiar issues that strike a chord with the electorate (resonance model) or bring new issues to the campaign. Relevant for the present case study is the awareness of the power involved in being the first to spot societal concerns and proposing answers to them. The fight for 'issue ownership' is often triggered by the interdiscursive process of reappropriating, borrowing, or 'stealing' the opponent's issues that strike a popular chord. Consequently, electoral platforms tend to converge to the centre in the candidates' desire for the largest possible audience appeal. Wu's (2011) outline of shifting positions in the KM T stance on the 'one China' policy clearly demonstrates how the кмт moves to the centre around electoral times and how the party differentiates between the general public (shift to centrist mode), Beijing (realist mode), and its core supporters' base (fundamentalist mode) as its targeted audiences.

Besides agenda setting and priming, both media professionals and political elites can also help people what to think about issues, which is achieved by the framing process. Finding its roots in psychology and sociology, framing, at the macro level, refers to 'modes of presentation that journalists and other communicators use to present information in a way that resonates with existing underlying schemas among their audience' (Shoemaker \& Reese, 1996, as cited in Scheufele \& Tewksbury, 2007:12). On a micro level, framing refers to the way people use the presented information in forming their impressions (Scheufele \& Tewksbury, 2007: 12). This cognitive mechanism goes further than agenda setting, in that it is a process in which the media 'select some aspects of a perceived reality and make them more salient in a communicating text, in such a way as to promote a particular problem definition, causal interpretation, moral evaluation, and/or treatment recommendation for the item described' (Entman, 1993: 52). Scheufele and Tewksbury describe the difference on the psychological level between agenda setting and priming on the one hand and framing on the other, as 'the difference between whether we think about an issue and how we think about it' (Scheufele \& Tewksbury, 2007: 14). ${ }^{6}$ Price and Tewksbury summarise the distinctions as follows:

6 McCombs (2004) has argued that framing is a type of 'second-level agenda-setting', but this theorising has been challenged by Scheufele, Price, and Tewksbury, who pointed out the conceptual differences between the effects of memory-based accessibility (agenda setting) and not-memory-based applicability (framing). See Price and Tewksbury (1997); Scheufele (2000); Scheufele and Tewksbury (2007). 
Agenda-setting looks on story selection as a determinant of public perceptions of issue importance and, indirectly through priming, evaluations of political leaders. Framing focuses not on which topics or issues are selected for overage by the news media, but instead on the particular ways those issues are presented (Price \& Tewksbury, 1997: 184).

Applied to the discipline of political science, media framing theory can be used to examine the way political actors affect public opinion by 'framing battles in policy debate', where 'political parties typically are at the center of the struggles to define and construct what is at stake' (Slothuus \& de Vreese, 2010: 642). Parties are said to play a vital role by mobilising and structuring public opinion and hence defining what the political conflicts are about. Linking the theory of 'motivated reasoning' with framing research, Slothuus and de Vreese argue that citizens are more likely to follow a frame if it is promoted by their preferred party and that such biases are more pronounced on issues at the centre of party conflicts (2010: 630). The Taiwanese political parties' different constructions of what is at stake in cross-Strait relations and their diverging conceptualisations of the '1992 Consensus' and the 'status quo' contribute to these party conflicts. Hence, my analysis zooms in on how the presidential candidates engage with these concepts.

\section{Contextualisation of the 2016 Elections}

The following paragraphs provide a brief historical contextualisation of the two most controversial notions in the 2016 presidential campaign, which are open to interpretation and triggered heated debates, i.e. the ' 1992 Consensus' and the 'status quo'.

\section{$1 \quad$ The Construction of the '1992 Consensus'}

Both the KMT and the Chinese Communist Party (ССP) have endorsed the '1992 Consensus', a framework for cross-Strait dialogue, backdated to a 1992 meeting between representatives of the Taiwanese Straits Exchange Foundation (SEF, 海基會) and the Chinese Association for the Relations Across the Taiwan Strait (ARATS, 海協會). From their perspective, an oral agreement was reached that there is only one China, the meaning of which is left to respective interpretations. The phrase ' 1992 Consensus' was masterminded by $\mathrm{Su}$ Qi (蘇起), Director of Mainland Affairs Council of the KMT government in 200o. Its content, including the 'one China principle' has since been construed by the кмт as the symbolic bedrock the status quo is built on (Fillingham, 
2016). The DPP has repeatedly contested the existence of a consensus and its validity, since the so-called deal was an interparty arrangement between the then ruling party, the KMT, and the СCP, but did not rest on a democratic consensus within Taiwan. The CCP subscribed to the phrase, as it offered them a useful discursive tool to reach their goal of unifying China. The KмT credited the cross-Strait détente to its adherence to this principle. In the 2012 presidential elections, the кмт formula met with a mimetic rival phrase, 'the Taiwan Consensus' (Taiwan gongshi, 台灣共識), coined by Tsai during her first bid for presidential office. It refers to the need for more democratic consultation with the Taiwanese citizens. In the 2016 campaign Tsai recycled the spirit of this message without articulating the same phrase. Meanwhile, the '1992 Consensus' formula resurfaced, most importantly, in the discourse of Chinese President Xi Jinping, who, well aware of the popular discontent with the KMT administration, insisted on acceptance of the formula as a sine qua non for cross-Strait dialogue.

Historical background to the reasons why Tsai Ing-wen stopped short of accepting the consensus is offered in chronicles of the early debates about the noun phrase in the Taiwanese media (Lams, 2012; Wu, 2011). From a green (DPP) perspective, the acceptance by both sides that there is only one China, construed as the prime content of the 1992 deal, would be tantamount to selling out to the Republic of China (вос) and surrendering even before the start of the cross-Strait negotiations. It is viewed as essentially a synonym for the Hong Kong model of 'one country, two systems'. Tsai's lack of endorsement of the '1992 Consensus' as the only option for dialogue entails a refusal to recognise the one-China principle enshrined in it.

To contextualise the Кмт interpretation of the '1992 Consensus' during the 2016 electoral period, one needs to distinguish between the two KMT presidential nominees. Quite late in the presidential campaign, on 17 October 2015, the кмт Chair and Mayor of New Taipei City, Eric Chu Li-luan (朱立倫) replaced the first nominee, Hung Hsiu-chu (洪秀柱) as the party's candidate. Hung had departed from the кмт party line by her controversial 'one China, same interpretation' remark, which went beyond the conventional кмт interpretation of the '1992 Consensus'. Chu was known to be more moderate on China relations while all the same advocating broadened bilateral ties with Beijing. Hung's ouster can be explained within Fell's analytical framework, stating that 'party positions are determined by internal balance of power between electionorientated and ideology-orientated factions and leaders' (Fell, 2005:4). As Fell argues, '[A]lthough most election-orientated leaders will not directly repudiate traditional party principles, they will de-emphasise ideologically-orientated 
policies that are seen as vote losers' (2005:4). Fearing that Hung's ideologically inspired policies would yield poor electoral results, the кмт rescinded her nomination and elected Eric Chu, who prioritised election in the assumption that moderate policies would be rewarded by voters.

\section{2}

\section{The Dynamic Meaning of Status Quo}

A second, more nebulous, concept in cross-Strait relations is the term 'status quo', which literally means 'leaving a situation the way it is'. On the one hand, the cross-Strait status quo has not been clearly defined. On the other hand, most Taiwanese people prefer the status quo, according to numerous opinion polls. ${ }^{7}$ It follows that strategic ambiguity in conducting China relations is condoned by a sizeable proportion of the electorate. The term is usually not premodified by the qualifications 'political' or 'economic', but Tsai Ing-wen implicitly decouples both spheres, as will be clarified further in the empirical analysis. Diachronic surveys of status quo changes during the DPP rule and shifting Kмт positions can serve as a historical contextualisation of current positions (Lams, 2012; $\mathrm{Wu}, 2011$ ). Wu sketches the competing versions of the status quo as follows: for the KMT, it means the ROC with sovereignty over the mainland and Taiwan, but jurisdiction only extending to Taiwan and the specific islands surrounding it, while for the DPP it means seeing Taiwan as an existing independent nation separated from China, and with 'Republic of China' as its current name ( $\mathrm{Wu}, 2011: 55)$.

Since the fostering of closer relations under the KMT government from 2008 to 2016, the status quo has changed in that cross-Strait communications have been institutionalised, resulting in a top-level meeting between the PRC and ROC presidents, 11 meetings of top officials from both sides, and the signing of 23 agreements. Yet, perceptions of the uneven spread in trade deals' benefits, as well as lack of transparency, legislative oversight, and proper consultation with the public, besides other issues of social injustice and deteriorating quality of life, gradually evolved into a widespread opposition by civil society groups and students. This popular unrest culminated in the 2014 Sunflower Movement with the occupation of the Legislative Yuan in 2014. The explosive force transmitted social activism into electoral politics, with the 2016 parliamentary election of five legislators of the New Power Party (NPP), established in the wake of the 2014 social movements (Hsiao, 2016).

7 See surveys by the Election Studies Center at National Chengchi University at http://esc .nccu.edu.tw. 
In view of these developments, how should one conceive of the status quo? For the Kмт, the status quo means endorsement of the '1992 Consensus', since this is perceived as bringing cross-Strait stability. From a DPP perspective, the contingency of a fluid process such as the status quo is naturalised by the KMT and CCP into the fixed concept of the ' 1992 Consensus', utilised for political expediency and presented as a 'fait accompli'. As Peng Ming-min (彭明敏), the father of the self-determinacy quest in Taiwan, once explained to the author, back in the late 199os, the status quo in Taiwan changes on a daily basis.

\section{Research Method}

As for units of investigation, a selection was made from the host of platforms through which candidates can spread electoral messages. The main units of analysis are speeches and texts by the protagonists, the DPP candidate Tsai Ing-wen and the кмT runner Eric Chu Li-luan. ${ }^{8}$ Televised debates were not selected for extensive analysis. The complexity involved in nonverbal communication requires a special analysis with different multimodal methodologies probing into the semiotics of visual language. Yet, the textual level of the official campaign videos and slogans of the main contenders was taken up for analysis.

Concerning the Км т candidate, my analytical focus went to Chu's campaign, but translated versions of speeches by the кмт's first nominee, Hung Shiu$\mathrm{chu}$, were also examined. Corpus selection comprised texts catering to foreign as well as domestic audiences. This article approaches the discourses through the available English-language materials. The data analysed were documents originally written in English for the international audience or translations from the original Chinese texts catering to the domestic population. These were retrieved from the official DPP party website or from foreign media's weblinks that published the relevant candidates' English-language speeches, interviews, and press articles. Secondary sources, like reports in local English-language media accounts also provided useful speech extracts and comments, especially since translated versions of the кмт texts were not found on its official website, save for translated versions of pro-KMT media accounts. Since the DPP official website ${ }^{9}$ provides ready access to original English texts and English

8 Speeches by the candidates' running mates were not selected for analysis as my main focus lay on Tsai's and Chu's messages.

9 See www.dpp.org.tw. 
translations of Chinese campaign materials, more information was found for the DPP camp. For the campaign texts of the PFP's candidate, James Soong Chu-yu (宋楚瑜), no translations were found, revealing a less internationalist outlook and leading to minimal international coverage. ${ }^{10}$ Furthermore, judging from the many opinion polls, this candidate was eclipsed by the main two contestants of the KMT and DPP. Hence, PFP texts were not included in this first phase of the project.1

Key discursive moments for the KMT and DPP were selected on the basis of their importance in the electoral cycle, spanning the announcement of their respective candidates in the first half of 2015 to the final weeks of the campaign in January 2016. This importance could be easily gleaned from the parties' websites and the domestic media accounts. The critical discourse moments for the DPP include the following speech events:

1. March/April 2015: announcement and nomination speech. ${ }^{12}$

2. June 2015: Tsai's U.s. tour. ${ }^{13}$

3. August-October 2015: Tsai Ing-wen's elaboration of her major reform policies (Kaohsiung speech, 16 August); publication of her (Chineselanguage) book, outlining visions for a better Taiwan (Tsai, 2015a).

4. December 2015/January 2016: final round of policy presentations including two TV debates, campaign trail in the south, and the DPP video ad 'Walk with the Children'.

For the KMT, the discursive moments are:

10 The author surveyed additional content and framing analysis of all Taiwan-related news and op-ed articles in 2016 in the Guardian, New York Times, De Volkskrant, NRc Handelsblad (two elite Dutch newspapers), De Morgen, De Standaard, and De Tijd (three elite Dutch-language Belgian newspapers). The result indicates that the third candidate, James Soong, was hardly mentioned, thus receiving no voice.

11 Yet, James Soong's campaign deserves in-depth analysis, given the novel tone he adopts in comparison with his past discourse and performance as a former кмт heavyweight in the authoritarian Кмт rule of the 1980 s and as the later PFP Chair.

12 Tsai Ing-wen's nomination speech on 15 April 2015 is entitled 'Restore Confidence and Light up Taiwan', see http://iing.tw/en/4, retrieved 6 June 2016.

13 The texts by the DPP candidate, targeting the U.s. community, comprise (1) Tsai Ing-wen's speech given at the Center for Strategic and International Studies (CSIS) in Washington DC on 3 June 2015, 'Taiwan Meeting the Challenges: Crafting a Model of New Asia Value', which underwent several phases of writing (as spelled out in Tsai, 2015a); and (2) Tsai's (2015b) article published in The Wall Street Journal on 1 June. 
1. June 2015: Hung Hsiu-chu's speech to the KMT Central Committee on the eve of her primary poll, 10 June.

2. July 2015: Hung's nomination speech at the KMT's National Party Congress, 19 July.

3. October 2015: replacement of Hung by Eric Chu at the congress meeting on 17 October.

4. Mid-November 2015: Chu's U.s. tour. ${ }^{14}$

5. Late November/December 2015: Chu's challenge to Tsai for a TV debate to discuss which party would be better able to maintain cross-Strait peace (29 November), Hung's joining Eric Chu at their new election headquarters, projecting party unity (6 December), and the KMT video ad 'One Taiwan'.

6. January 2016: final round of policy presentations, including two TV debates, China Times news editorials, posted on the KM few days before the polling day, and the KMT video ad 'Born in the 5os'.

The study did not impose a predetermined analytical model on the data with a codebook of variables, often used in quantitative content analyses. It examined discursive strategies that accumulatively indicate ideological patterns in prioritising and framing issues. From the large toolbox of discursive practices available to language users, attention is drawn to two relevant tactics, found in the texts on a macro-textual and a micro-sentential and lexical level: (1) highlighting/prioritising or backgrounding/defocusing on certain themes, and (2) framing issues along partisan ideological orientations through semantics and argumentation.

An investigation of the first tactic offers insights into the ways the candidates set the agenda and shape the electorate's considerations when making judgements about the candidates or the issues (priming). Examining the order in which issues are touched upon or the presence/absence of issues renders an idea about priorities given to issues. Audience design plays a role, in that priorities differ hinging on the type of public that is addressed. Secondly, while issue framing operates in numerous ways, one tactic is singled out because of its prominence in the corpus, namely the causal projection, constructing a series of hypothetical scenarios, based on postulated causal links. The rhetorical aim is to envision an undesirable electoral result, elicited by a chain of predictable reactions.

14 The texts by the кмт final nominee, catering to the U.S. community include (1) Eric Chu's article (2015), published in the Washington Times on 12 November; and (2) an interview with Eric Chu, published in The Washington Post on 17 November (Wan, 2015). 


\section{Empirical Analysis: The 2016 Taiwanese Presidential Candidates' Campaign Discourses}

Findings of the analysis are divided into three sections. The first part lists the priorities of the respective parties in terms of issues and ideology. It is followed by an interpretative analysis of the most obvious reasoning patterns in framing the issues and the opponent's campaign style.

\section{$1 \quad$ Issue Salience and Agenda Setting/Priming}

After formulating some general remarks about the parties' issue priorities, more details are presented about the candidates' agendas on the economic and sociopolitical level as well as their proposed cross-Strait and foreign policies. As will emerge from the diversity of issues discussed below, the focus in the international press on primarily two issues (cross-Strait relations and the DPP campaign style) is a heavy reduction from the variety of issues that featured on the electoral platforms. It shows the agenda-setting practice by the international media, as they publish only what they deem important. Although this article does not aim to analyse the reasons of this selective practice, one still wonders why the foreign media prefer to echo the Кмт (and ССР) agenda of spreading the scare story in the case of a DPP victory. Was the platform of the DPP not clear enough? Was it not well translated to the foreign media? Was there a lack of interest in domestic Taiwanese affairs? Is the China threat story more dramatic or more familiar to the foreign community? While it is difficult to answer these questions, it delivers more tangible results to examine the agendas of the electoral candidates themselves and to see what issues were prioritised.

Former analyses about discourses during the Ma Ying-jeou ruling era concluded that Taiwan was passing from a period rife with antithetical national identity struggles to an era of civic nationalism in which domestic issues of concern, such as a sluggish economy, rising unemployment, degrading environment, and income disparities dominated the debates like in any other democratic country (Cole, 2015; Lams \& Liao, 2011). This trend has been further consolidated, judging from the numerous themes that have surfaced during local municipal and county elections. A public mood, especially among the younger generations, anxious about deteriorating life quality and frustrated about 'black box' governance under the кмт rule, transformed Taiwanese society, formerly divided because of ethnic nationalism, into a citizenry demanding transparent governance and greater participation in national politics.

The 'bread-and-butter' issues that concern the daily livelihood of ordinary people are prioritised in the DPP campaign. Domestic Taiwanese concerns, 
such as growing social inequality, stagnant wage growth, and unaffordable housing, a theme already present in the 2012 DPP campaign, resurfaced in 2015 after Tsai travelled the island to probe into the most pressing needs of various sectors in society. The economy, food security, and long-term care for the elderly also featured as the top three priorities in a DPP-led survey. Cross-Strait relations ranked 1oth in place, ${ }^{15}$ which explains its lower salience in the 2016 DPP campaign.

When addressing the domestic constituencies, both political parties shift their focus from the divisive ideological issues concerning self-identification and the sensitive question of Taiwan's sovereignty to economic matters. Both candidates share a concern about the inequitable wealth distribution, an issue that the кмт borrowed from the 2012 DPP campaign. Another proposal by $\mathrm{Chu}$, which appears remarkably similar to the DPP platform, is the 'three bows, four arrows' economic strategy, presented late in the campaign in early January (Hsu \& Low, 2016). However, the differences between the platforms are more obvious than the parties' convergence.

\section{Differences in the Parties' Roadmap to Economic Growth}

Although a shared priority is the reinvigoration of the economy, different avenues are proposed to reach this goal. Since the major planks of Chu's platform are cross-Strait peace, economic development, and social stability, with crossStrait peace serving as the 'foundation for the other two goals' first (Wang, Hsieh, Kuo, \& Chang, 2015), the кмт road clearly passes through China. To achieve peace in the Taiwan Strait, adherence to China's prerequisite, the '1992 Consensus', is the only way to go. This issue features in almost every speech or text analysed from the selected кмт campaign materials and marks a stark divergence from the DPP priorities. Framed by the KMT as populist, the DPP adopts a people-first approach on the economic, social, and political levels. In the DPP's economic platform, an inclusive and regionally balanced growth comes top of the agenda. Economic reinvigoration is to be achieved by a new focus on innovation, allowing local governments to share in the task of stimulating growth together with the central government.

A second driver for economic growth is expansion of global ties, an issue that naturally receives high attention in speeches and texts addressing a foreign audience. While the кмт makes a detour to China, given its focus on China-centric economic agreements and its ambition to join the RCEP (Regional Comprehensive Economic Partnership, led by China) and the AIIB

15 This was confirmed in the author's interview with James Huang, DPP's Director of International Relations, on 29 March 2016. 
(Asian Industrial Investment Bank), the DPP reaches out to the international community by trade diversification to diminish its lopsided economic overdependence on China. In this sense, Tsai can be seen to change the economic status quo with China and decouples economics from politics in the crossStrait status quo. Besides engaging ASEAN countries and India through her proposal for a new Southbound policy, her priority is to advance talks with the U.s. about the U.s.-Taiwan Trade and Investment Framework Agreement (TIFA) and prepare for participation in the Trans-Pacific Partnership, led by the United States.

\section{Differences in the Parties' Sociopolitical Agendas}

The issues mentioned in this section primarily emerge in texts and speeches addressing domestic audiences. On the sociopolitical level, the DPP candidate promises to expand Taiwan's social welfare benefits, increase government investment in social housing, and improve the long-term senior care system. Numerous policy proposals are offered in Tsai's nomination speech on ${ }_{15}$ Aprill ${ }^{16}$ and are expounded in her 16 August speech on the campaign trail in Kaohsiung, ${ }^{17}$ where she addresses the local audience, her core base supporters, with an administrative blueprint of five major political reforms, five major industrial development objectives, and five social stability pledges. Referring to her previous 2012 campaign promises, Tsai takes credit for spotting societal problems early on, such as the lack of social housing. She pledges to fight for generational justice and bring transitional justice by offering an official apology to the Aborigines, which was subsequently articulated in the summer of 2016, and to restore historical truth concerning national violence against native Taiwanese during the White Terror. As Tsai puts it in metaphorical terms, 'only in this way can the sunshine of democracy truly light up Taiwan politics'. ${ }^{18}$ Tsai urges all parties to put an end to social antagonism and shake off malicious political fighting. Arguing in favour of 'unity of the country' and 'internal solidarity', she advances her belief in (domestic) consensus and communication. While not expressing the phrase 'Taiwan Consensus', its spirit survives.

\footnotetext{
16 'Restore Confidence and Light up Taiwan', http://iing.tw/en/4.

17 Tsai's speech on her campaign trail in Kaohsiung 'Vote 2016: Five Major Reforms', $16 \mathrm{Au}$ gust 2015. For the original Chinese version, see http://iing.tw/posts/21. The speech was translated into English by an anonymous translator in Taipei and posted on the DPP campaign website at http://thinking-taiwan-com/vote-2016-tsai-ing-wens-five-major-re forms, retrieved 6 June 2016.

18 Tsai's Kaohsiung speech, 16 August 2015.
} 
While the DPP's focus is on the young and the elderly, the social plank in the KMT's platform is Chu's promise to protect the rights of workers and improve the labour environment, with the goal of enhancing workforce competitiveness. The KMT's social platform is eclipsed by the predominance of economics and the need for restoring party unity in the face of infighting, exacerbated by the ousted first nominee, Hung Shiu-chu, late in the campaign period. Not only does the new candidate prioritise party unity, but he also puts national unity high on the agenda. As is evident in his slogan and video ad 'One Taiwan', he laments the polarised society and puts the blame on the 'enemy' (i.e., the DPP).

Differences in the Parties' Cross-Strait Relations and Foreign Policies The DPP candidate advocates a consistent, predictable, and sustainable relationship with China, based on the will of the Taiwanese people, which means normalising the communication patterns beyond the KMT/CCP framework. ${ }^{19}$ Cross-Strait relations consistently feature in the tail of Tsai's speeches and only serve to foster a stable domestic environment and regional peace. Foreign relations are not highlighted in speeches to the local Taiwanese. When addressing the U.s. audience, Tsai reshuffles issue order and foregrounds foreign policy. This signals a well-considered and clear distinction between international image-building and domestic imperatives. Her international outlook shines through the numerous areas of international collaboration she proposes to face global challenges. It can also be gleaned from the many materials available in English or via translated versions from Chinese texts. This contrasts sharply with the Кмт campaign which features hardly any original texts in English or translated versions. The only two campaign texts addressing the U.s. audience, a commentary in the Washington Times (Chu, 2015) and an interview with The Washington Post (Wan, 2015), shows a candidate with less international outreach, shorter English-language texts with fewer concrete policy proposals, and a directly negative campaign against the opponent.

While Tsai indirectly criticises the кмт by exposing the challenges facing the Taiwanese under the кмт rule, the issue which ranks first in her speech presented at the Center for Strategic and International Studies (CSIS) in Washington $\mathrm{DC},{ }^{20}$ she does not demonise the кMT in front of an international audience. Instead, she highlights the DPP achievements in securing freedom and democracy, much cherished values shared by the U.s. and Taiwan. Her four-pronged foreign policy places broadened u.s. cooperation in first place

\footnotetext{
19 Tsai's nomination speech, 15 April 2015.

20 Tsai's csis speech, 3 June 2015.
} 
and principled relations with China last-yet said to be the core goal of her administration. Highlighting themes of U.s.-Taiwan mutual interest in regional peace and their historic friendship, Tsai shows her commitment to enhancing cooperation with the U.S. on security issues. To assuage U.s. concerns about her capability of handling China relations, she promotes implementation of a transparent process to enhance trust and cooperation across the Taiwan Strait and makes the following promise: 'Through principled engagements, joint initiatives and dialogue, I'll ensure that the spirit of cooperation that has guided the betterment of China-Taiwan relations continues' (Tsai, 2015b). The noun phrase 'spirit of cooperation' represents for her the essence of the 1992 talks. Quite consistently, Tsai reiterates references to this 'spirit of cooperation' throughout the campaign whenever confronted to be more specific on her position towards the ' 1992 Consensus' and the meaning of status quo, which will be elaborated further below.

In Eric Chu's texts targeting a foreign audience, foremost attention goes to maintaining cross-Strait 'peace and stability', equated with a KMT victory, and averting 'imminent war', associated with the DPP. In his article in the Washington Times, addressing the American readership, Chu credits Ma Ying-jeou with creating the Taiwan-China rapprochement, resulting in regional peace and stability (Chu, 2015). This issue obviously resonates with the U.s. audience. While invoking American support for the KMT's China policy, he juxtaposes KMT's self-appraisal with negative portrayals of a dodging Tsai, who is criticised for deploying empty rhetoric and ambiguous language.

\section{Discussion: Primacy of Civic Issues over Ideology?}

To conclude this section on issue salience on the electoral agendas, let us examine the calibration between the civic issues, as discussed so far, and the ideological issue of national identity, formerly highly prominent in Taiwanese presidential elections. Explicit appeals to Taiwan nationalism or reference to ideological debates on cross-Strait relations in terms of national identity are absent in the data analysed. Yet, one can derive the ideology underpinning the candidates' platforms from the implicit messages of the parties' slogans and video spots aiming at the Taiwanese voters. For the км т candidate, the slogan and video ad 'One Taiwan' symbolically refer to party unity and, by extension, unity among the Taiwanese citizens. For the DPP, the slogan 'Light up Taiwan' and the video ad 'Walk with the Children' both reflect Tsai's people-centred approach, aiming to offer the younger generation renewed hope by presenting a platform based on innovation and reform. Similarly, ideological preferences can be uncovered at the macro level of the candidates' speech titles and the 
headlines of their commentaries published in the foreign media. Tsai entitles her texts as follows: 'Restore Confidence and Light up Taiwan' (nomination speech); 'Taiwan Meeting the Challenges: Crafting a Model of New Asian Value' (csis speech); and the article, "Taiwan can build on U.s. ties: A more consistent relationship with China requires open channels of communication, both with China's leadership and the Taiwanese people', published in The Wall Street Journal (Tsai, 2015b). The English-language article (in the Washington Times) authored by Eric Chu himself in the period investigated carries the title 'CrossStrait peace on the line: A stable Chinese triangle must be the goal' (Chu, 2015). The content of these headlines clearly shows agenda priorities.

The absence of explicit references to the ideologically divisive issue of national identity confirms the tendency of party convergence, in which Taiwanese politicians and parties appeal to the median voter (Clark, 2005; Rigger, 2016b; Wu, 2011). Preference of party politics over ideology is evident in the кмт's decision to replace the ideology-orientated Hung Hsiu-chu by the moderate, election-orientated кмт Chair Eric Chu, because of Hung's oldstyle кмт nationalist rhetoric. Deemed too ideological and out of touch with the electorate for wanting to sign a political peace agreement with China, and for having articulated her desire to push beyond the ' 1992 Consensus' to a 'one China, same interpretation' framework, Hung was replaced by Eric $\mathrm{Chu}$, who espouses a moderate agenda, closer to the centre of the political spectrum. Since Hung was perceived to move too far away from the centre, the KMT risked losing votes. This argument also applies to the DPP. Compared with her first presidential run in 2012, Tsai is more cautious not to estrange the electorate with the previously used sensitive slogan 'Taiwan Consensus'. Tsai Ing-wen's attitude of 'sitting on the fence' as a strategic move to appeal to the Taiwanese median voter suggests current validity for Wu's claim about the Taiwanese parties' 'vote-maximizing strategy' (Wu, 2011: 67) of the 1990s, in which parties strategically moved towards the centre. Wu sees 'the centripetal impact of moderate public opinion on Taiwan's parties' to 'underlie the appeal to the median voter' (2011: 57).

Yet, public opinion in 2016 is no longer as moderate as in the 1990s. Civic nationalism has become a social force to be reckoned with, especially since the 2014 Sunflower Movement. Also, as Fell argues, 'there are limits to how far the party can move from its core ideology to avoid factional backlash' and 'in all parties there has been resistance to what is seen as betrayal of party ideals in the name of electoral benefit' (Fell, 2005: 5). Loyalty to core ideological principles can be derived from Tsai's resistance to accept the '1992 Consensus' despite being continually interpellated by the кмт and the threats issued by China. While adopting a conciliatory tone toward Beijing, at least 'more 
accommodating by recent DPP standards' (DeLisle \& Dreyer, 2016: 468), Tsai has equally been consistent in refusing to endorse the 'one China principle'. She will not accept any precondition for dialogue with China and will follow the democratic will of the Taiwanese people. This constitutes an implicit interdiscursive link to the same spirit of her 2012 slogan 'Taiwan Consensus', but this time the speech act remains indirect. The ' 1992 Consensus' formula has been vehemently rejected by the DPP since the early 200os. Although it is impossible to detect the balance between candidates' ideological convictions and political strategy, Tsai Ing-wen's postelectoral discursive acts, despite Chinese threats and retaliation, reveal a deep loyalty to the basic tenet of the DPP that acceptance of the '1992 Consensus' would mean a sell-out of Taiwan.

Ideology also survives in the кмт camp. Chu consistently repeats that the KM T's rapprochement policy within the '1992 Consensus' framework has created warmer relations with China and enabled expanding communication with Korea and Singapore. Chu does not diverge an inch from the KMT's steadfast belief in this panacea for improving relations with China. Although the КМт loss in the 2016 elections, both on the executive and legislative level, is generally attributed to its government's speed in pushing through China deals and its lack of transparency and public consultation for handling the ChinaTaiwan relationship, the party and its candidate, Eric Chu, continue to support the Kмт's China policy. Chu acknowledges that the expected revenues from economic trade deals across the Strait should be more equitably shared among the Taiwanese citizenry, but he still defends Ma Ying-jeou's 'realist' rapprochement policy (Wu, 2011: 66).

Now that we have discussed issue priority on the agenda, I shall next take an interpretative approach in examining the framing process, including the perspectives and definitions involved in presenting the issues as well as metapragmatic comments on the participants' campaign style. ${ }^{21}$

\section{$2 \quad$ Issue Framing}

Although all four aspects of Entman's (1993) framing theory are relevant, only the first one, problem definition, is selected for investigation here to limit the analytical scope. The process of framing or steering the essence of the issue in a certain direction can be deconstructed by examining reasoning and argumentation patterns. Most significant in the campaign materials are the

21 The term 'metapragmatic' denotes the awareness of the power of language and draws the attention to how speech utterers refer to the use of language (by themselves or others) on a metalevel. 
often repeated causal projections and constructed equations or correlations between unrelated issues into seemingly coherent packages. Both parties employ these practices, but the Kмт securitisation narrative of the 'China threat' scare story, which permeates all campaign speeches, leaves a negative imprint compared with the hopeful DP P message of reform to 'light up Taiwan'.

\section{кмT: Securitisation Narrative-'Non-endorsement of 1992 \\ Consensus equals cross-Strait instability'}

The most obvious causal projection by the KM T runs as follows: (1) China wants endorsement of the 1992 Consensus to keep cross-Strait relations smooth; (2) DPP does not endorse the 1992 Consensus; (3) voting for the DPP invites regional instability. The кмт consistently securitises the electoral event with the reifying claim that nonendorsement of the ' 1992 Consensus' equals cross-Strait instability. As Chu's China-centric position favours maintaining and broadening cross-Strait cooperation, he construes Tsai's refusal to endorse the '1992 Consensus' for handling cross-Strait relations as nothing but a threat to regional stability. The presidential choice is thus equated with a choice between chaos and stability, embodied by adherence to the ' 1992 Consensus'. Following Chu's invocation of doom scenarios with statements like 'a comprehensive defeat in January would give carte blanche to the DPP and endanger relations with China' and questions like 'what if the DPP would attempt to amend the Constitution to alter the essence of the Roc?', he debunks the perception that he might be attempting to frighten the public. ${ }^{22}$

Since the late 1990s, the 'China threat' has formed a red thread in the KMT electoral discourse, some кмT-leaning media (Lams, 2008: 160), and a sizeable part of the international media discourse about Taiwan affairs, which seems to have been influenced by the кмт narrative. This securitisation discursive practice is based on Beijing's repeated warnings to instil a sense of fear in the Taiwanese population. The tactic of fearmongering originated in the late 199os, was stepped up during the Chen Shui-bian era, and has been intensified since Chinese President Xi Jinping assumed power.

Another example of causal projection is the construction of a positive correlation between closer China relations and economic growth. It surfaces in the following set of кмт arguments: (1) If Tsai wins the election, there will be

22 Eric Chu's nomination speech, 18 October 2015 (Source: 'Chu: "Tsai unable to maintain cross-Strait status quo without 1992 Consensus"', 19 October 2015, KMT website compilation of all Taipei newspapers; retrieved on 8 March 2016 from www1.kmt.org.tw/english/ page.aspx?type $=$ article $\&$ mnum $=112 \&$ anum $=16872$ ). 
fewer cross-Strait agreements; (2) fewer cross-Strait deals means a deteriorating Taiwanese economy; so (3) it can be logically expected that a choice for Tsai will result in a declining Taiwanese economy. For Chu, the only party who can bring economic prosperity is the KMT, because it can guarantee smoother cross-Strait relations. Yet, this conflation of the three issues, 'cross-Strait peace', 'economic development', and 'social stability' does not reverberate across the campaign materials. It is not foregrounded, as the KMT realises the tactic will no longer entice the general electorate given the growing public perception of economic overreliance on China. Furthermore, economic growth, as promised in the $2012 \mathrm{KMT}$ presidential campaign, had not been distributed in an equitable fashion to all sectors of the Taiwanese society and had stirred dissatisfaction among sMEs and farmers.

DPP: 'DPP victory equals recovering economic autonomy'-

Implicitly, 'Кмт victory equals continuation of the problematic past'

A similar scare story tactic emerges from the DPP campaign materials, albeit less framed in hypothetical scenarios or reified equations. In other words, the warnings are not as explicit as in the Км Typotheses. But by presenting a constructive alternative in the form of trade diversification, Tsai implicitly warns against putting all economic eggs in the same China basket, which will threaten the local Taiwanese economy and political autonomy. Underlying the equation between a DPP victory and recovering economic autonomy is the negative retrospective appeal that a KMT victory equals continuation of the problematic past, or that no risk management equals loss of autonomy for Taiwan. This implicit criticism presents a negative mirror to the messages of reform to light up Taiwan'. As can be expected of an opposition party, Tsai's speeches start out with an overview of the current challenges but are directly followed with policy proposals clad in a hopeful story of reform.

It deserves mentioning that for both securitisation narratives, articulated by the DPP ('loss of economic autonomy if the KMT wins') and the KMT ('loss of cross-Strait stability if DPP wins'), unfortunately, the scare stories are grounded in projections based on current realities of China resorting to retaliatory measures. $^{23}$

23 Within one month after President Tsai's inauguration in May 2016, China's Taiwan Affairs Bureau, which handles its relations with Taipei, suspended the official cross-Strait communication mechanism that provided for regular contact between the two governments. Since then, the Chinese leadership has been squeezing Taiwan out of international breathing space. 


\section{$3 \quad$ Framing the Opponent's Campaign Style}

As some international media narratives framed the DPP candidate's campaign as rather vague, it is also worth looking into the way this featured in the campaign discourses. Besides presenting the issues from a certain perspective, the candidates also frame each other's campaign style by engaging in negative characterisations of the opponent, while all the same bestowing laudatory comments on the self. Mudslinging and self-appraisal are discursive practices endemic in electoral campaigns and not peculiar to the Taiwanese case. This article only zooms in on the most striking framing process of the opponent's campaign style, namely, the KMT's depiction of Tsai's campaign as being vague. Although there are plenty of other characterisations of 'the Self vs. the Other' worth discussion, ${ }^{24}$ the present focus remains on what was highlighted in the international media, that is, the KMT securitisation narrative and Tsai's vagueness. Suffice it to mention that both candidates excel in taking credit for issues that are welcomed by the public, be it democratisation efforts, being the first in detecting societal problems, creating cross-Strait stability, or being a pragmatic problem-solver. As for negative campaigning in Tsai's texts, her speeches generally start with a survey of the many challenges the Taiwanese face, indirectly condemning the Км T administration's negligence in its duty of care to the Taiwanese people. Yet, her focus lies on how to turn Taiwan around rather than demonising the Other or attacking the кмт candidates' character or their campaign.

KMT's Framing of the DPP Campaign as Hollow Rhetoric and Tsai Ing-wen as 'Empty Spinach'

Throughout the campaign period, Tsai is continually confronted with KMT interpellations on how she intends to keep the cross-Strait dialogue going without accepting China's prerequisite, the ' 1992 Consensus'. In the first (Chinese-language) television debate, Chu challenges her to give a clear answer and legitimises his request as follows: 'Because I don't understand you, the Taiwanese people don't understand you, and the international community doesn't understand you, chairwoman Tsai, even if you still want to be vague,

24 Just a few of these additional characterisations include the кмт's negative introspection of having been pushed into a minority role and muffled by majority voices. This 'victimisation' frame is especially salient in the rhetorical speeches by the first Кмт nominee, Hung Hsiu-chu and the кмт video ad 'Born in the 5os', published during the final weeks before the elections in a desperate appeal to a specific (Mainlander) segment of KMT voters to come out and cast their vote. Another example is the KMT's negative framing of the DPP as a populist party, instilling hatred of China in the hearts of the younger generation. 
Taiwan's future cannot be vague' (Sun, 2015). While the '1992 Consensus' issue has no original salience in Tsai's speeches, it repeatedly comes to the fore in press conferences, the TV debates, or in responses to prompts by Eric Chu. Being accused of a lack of substance, at best she is said to be deceiving herself, since 'how could she stabilize cross-Strait relations and win the Mainland's trust without accepting its bedrock principle?' (кмт, 2015).

Tsai's discursive stance of neither accepting nor repudiating the '1992 Consensus' formula as the political foundation for cross-Strait dialogue has been framed as empty and ambiguous rhetoric. While she does not offer the answers expected from Beijing, she refrains from uttering aggressive statements concerning the ' 1992 Consensus'. Throughout the campaign materials, she remains consistent in her promise not to provoke Beijing, and to remain 'consistent, responsible, and predictable' in her China policy. She repeatedly clarifies her position in reassuring statements that she 'respects' the 1992 meetings as a 'historical fact' concerning a common acknowledgement to seek common ground despite differences, but she stops short of accepting the existence of an agreement about the 'one China' principle, as demanded by China. While demonstrating a willingness for dialogue, she also adheres to her principled position not to be cornered by the formula that her party has consistently perceived as a myth. This ambiguity facilitates her pragmatic navigation between the expectations of the Chinese leadership, the U.s., the swing voters who are disenchanted with the кмт but not necessarily anti-China, her DPP supporters, and the Taiwanese nativist base (Fillingham, 2016).

A deeper explanation of how the DPP candidate approaches the two most controversial issues in the campaign, the ' 1992 Consensus' and the 'status quo', as mentioned in this article's contextualisation section, is in order. Tsai's principled position follows the DPP line in perceiving the formula ' 1992 Consensus' as a semantic trap related to its core ideological concern, Taiwan's sovereignty. Adopting this logic, Tsai prefers to 'put aside differences of diverging interpretations and phraseologies' and chooses to focus on the spirit of what was discussed back in the historical meeting of 1992, which she interprets to be a 'mutual understanding to continue looking for common ground despite differences to conduct exchanges' (Chen, 2015). For her, accepting the '1992 Consensus' is only one option, but it cannot be imposed as a precondition for talks. In a San Francisco press meeting on 8 June 2015, Tsai frames the DPP status quo in terms of two bases and two meanings (Chen, 2015). It is based on the 'existing Roc constitutional order' and the 'accumulated outcomes' of past cross-Strait negotiations going back 20 years. This extended period includes all cross-Strait contacts, facilitated long before the кM took office. Tsai thus debunks the кмт argument about their particularity in deserving credit for 
facilitating cross-Strait dialogue. Her definition of the status quo includes two principles: (1) sustaining the freedom and democracy enjoyed by the people of Taiwan; and (2) preserving the present status of regional peace and stability and the stable development of cross-Strait relations. In the hope that the CCP can break out of the кмт/ССР framework to find the greatest common denominator with the DPP, she presents the DPP as open to constructive dialogue with the CCP.

Despite this clarity in definitions of the sticking points in cross-Strait relations, Tsai Ing-wen is still deemed ambiguous for not revealing more strategic cards or showing the roadmap on how to conduct this proposed dialogue in the case China fails to be a willing partner. As for the other campaign issues, Tsai has also been criticised for not reflecting her progressive aspirations in concrete policy proposals (Rigger, 2016a). Her speeches are replete with concrete issues, but not all of them are translated into specific measures. What she will deal with is clear, how she will operationalise her proposals remains opaque. When criticised for failing to propose concrete measures on how to achieve economic growth, Tsai responds that she will not present unreachable slogans with definite figures, as Ma Ying-jeou had previously done with his '63-3' campaign promise, and which Eric Chu was luring the electorate with. ${ }^{25}$ For Tsai Ing-wen, 'people are not statistics'. ${ }^{26}$ She promises to establish special taskforces on every issue and to elaborate more details along the way, cautiously working on policy 'step by step' while monitoring public and international reactions. Arguably, if policy matters involve other partners, such as the PRC, it is not strategic to put all cards on the table, since it takes two to tango. But in urging Tsai to openly reveal her follow-up plan, should Beijing not be rational enough to continue a cross-Strait dialogue, the кмт candidate preemptively challenges Tsai's capability of handling the Chinese leadership.

\section{Conclusion}

This paper used a qualitative method to examine how the presidential candidates engaged in public agenda setting and priming practices through highlighting or defocusing on particular issues, and how they deployed discursive mechanisms such as framing the issues to forge certain connections between

\footnotetext{
25 Eric Chu promised to boost minimum wages to NT\$30,0oo wages per month (c. US\$1026) during the first Tv debate on 27 December 2015.

26

Tsai's nomination speech, 15 April 2015.
} 
various concepts and framing the opponent's campaign style to discredit his or her public image. Findings of issue salience reveal a larger range of issues than a first glance at the international media coverage suggests, in that the latter seems to only focus on cross-Strait instability in the case of a DPP victory. Yet agenda setting and priming public opinion is not only undertaken by media professionals. The electoral candidates also prioritise certain issues over others by 'attending to some problems and ignoring others' with the intention to 'alter the standards by which people evaluate government' (Iyengar et al., 1982: 849) or, in this case, assess the electoral platforms and candidates. This priming practice is evident in the campaign materials targeting both the international and the domestic audience to win support for the respective party platforms. Depending on the audience focused on, the candidates adjust their agendasetting priorities, which neatly illustrates the agenda-setting theory. When addressing the U.s. community, foreign policy, including cross-Strait relations, ranks higher on the agenda, whilst bread-and-butter issues are prevalent in the speeches on the local hustings, catering to the domestic constituencies.

Quite captivating and deserving of an in-depth analysis on its own is the interdiscursive engagement with the candidates' issues and language. Private ownership of themes such as 'democracy', 'justice', and 'love for Taiwan' is vividly claimed and debated, especially when parties' symbols are usurped in sophisticated ways either by mimicry, parody, or simply recycling - the reappropriation of old wine in new bottles. A case in point is the KMT's 'One Taiwan' slogan, most reminiscent of DPP parlance, brought to the fore to show that the KмT too can love Taiwan.

In general, reinvigorating the economy is a recurrent campaign issue with high salience for both the KMT and the DPP. The DPP prioritises those issues, which, in accordance with its opinion poll, resonate most with the Taiwanese population that is more interested in quotidian matters, governance, and performance of political parties and their leaders rather than divisive ideological positions. Whereas securing cross-Strait stability and continued rapprochement with China is high on the KMT's agenda, it consistently features at the bottom of the DPP candidate's speeches. Yet, Tsai takes a consistent stance on China policy whenever prompted to clarify her position. Tsai's platform pits democratic ideals against former кмт backroom or 'black box' government operations, sharing resources and governance against monopolising them, and leaving open all avenues in cross-Strait dialogue rather than limiting the options to acceptance of the ' 1992 Consensus'. With a 'people first' approach, the DPP candidate advocates reform to 'light up Taiwan', whilst the KMT contender Chu highlights party and national unity in his slogan 'One Taiwan'. 
While this study does not analyse framing effects on the audience, it points out the framing process in the candidates' presentation and argumentation of issues, how connections between issues are forged and how the contestants in the race are characterised. When it comes to framing the campaign style of the opponent - a practice not unique to the Taiwanese electoral scene- the most direct negative campaigning concerns the KMT's portrayal of Tsai's strategic ambiguity about the ' 1992 Consensus'. This depiction is also echoed in the international media. As for framing the campaign issues through argumentation, the кMT equation of a standstill in cross-Strait relations with economic marginalisation for Taiwan is downplayed, in comparison with its 2012 presidential campaign, strongly defending the ECFA deal with China. This reasoning pattern is now overshadowed by the KMT's emphasis on its unique ability to bring stability in the cross-Strait. The DPP's conflating of the variables 'more China deals' with 'loss of economic autonomy' is present at an implicit level, wrapped in less dramatic scare stories. It is articulated in a positive message of hope and reform if the DPP gets the popular mandate.

The clearest example of issue framing in this election campaign is the argumentation logic underpinning the KMT securitisation narrative, which involves bold negative prospective appeals and projections about a disastrous political future if the DPP opponent wins. When assumptions are naturalised as truth claims, it is not easy for an uncritical ear to demystify the reifying nature of collating two separate processes, even if their relationship is constructed in a hypothetical form. The deconstruction of the perceived fallacious equation underlying the KMT's 'China threat' narrative was made by DPP's Taichung Mayor, Lin Chia-long, arguing that 'the "1992 Consensus" cannot be presented as an equilibrium point for stability. Nor can it be accepted by Tsai, because of the mandate she received from the people to oppose it, but she knows the red line and is pragmatic. ${ }^{27}$ Since the DPP team took office in May 2016, it has remained adamant in its wish to explore alternative avenues of finding an entente with China. The party tends to believe in the adage that one need not bend before the wind blows. Therefore, it will not accept the '1992 Consensus' as the only option for Taiwan to engage with the Chinese leadership. Less risk-averse than the Kмт, who adopts a more 'realist' stance toward China when in power and during nonelectoral times ( $\mathrm{Wu}, 2011: 66)$, the DPP exhibits considerable confidence and harbours idealistic hope that Beijing will be rational enough not to resort to armed conflict. It takes two to tango, and in the cross-Strait saga, more partners share the dance. What the next steps will be, time will tell.

27 My interview with Lin Chia-long, Taichung, 25 March 2016. 


\section{Acknowledgements}

This research has been sponsored by the 2016 Taiwan Fellowship, issued by the ROC Ministry of Foreign Affairs (MOFA). The author wishes to thank MOFA for facilitating research at the Institute of Political Science, National Sun Yat-Sen University, Kaohsiung, from 15 January-April 2016.

\section{References}

Chan-Olmstead, Sylvia M. and Chiu, Peilin (1999) 'The impact of cable television on political campaigns in Taiwan', International Communication Gazette 61(6): 491-509. Chen, Emily S. (2015) 'The DPP's strategic ambiguity toward China', Centre for Strategic International Studies, Honolulu, 19 August. Retrieved 30 January 2018 from www .csis.org/analysis/pacnet-51-dpp's-strategic-ambiguity-toward-china.

Chu, Eric Li-luan (2015) 'Cross-Strait peace on the line: A stable Chinese triangle must be goal', Washington Times, 12 November. Retrieved 30 January 2018 from www.wash ingtontimes.com/news/2015/nov/12/eric-li-luan-chu-china-taiwan-peace-on-the -line.

Chu, Yunhan (2005) 'Taiwan's year of stress', Journal of Democracy 16(2): 43-58.

Clark, Cal (2005) 'The paradox of the national identity issue in Chen Shui-bian's 2004 presidential campaign: Base constituencies vs. the moderate middle', Issues and Studies 41(1): 53-86.

Cohen, Bernard C. (1963) The Press and Foreign Policy, New York: Harcourt.

Cole, Michael (2015) 'Vote 2016: The Wang controversy is a symptom of KMT sclerosis', Thinking Taiwan, 10 December. Retrieved 8 February 2016 from http://thinking-tai wan.com/wang-controversy-kmt-sclerosis.

Copper, John (2003) 'Taiwan: democracy's gone awry?', Journal of Contemporary China 12(34): 145-162.

Damore, David F. (2002) 'Candidate strategy and the decision to go negative', Political Research Quarterly 55(3): 669-685.

DeLisle, Jacques and Dreyer, June Teufel (2016) 'Taiwan in the Tsai era', Orbis 2o(6): 465-472.

Druckman, James N.;Jacobs, Lawrence R.; and Ostermeier, Eric (2004) 'Candidate strategies to prime issues and image', Journal of Politics 66(4): 1180-1202.

Entman, Robert M. (1993) 'Framing: toward clarification of a fractured paradigm', Journal of Communication 43(4): 51-58.

Fell, Dafydd (2005) Party Politics in Taiwan: Party Change and the Democratic Evolution of Taiwan, 1991-2004, London: Routledge.

Fell, Dafydd (2011) Government and Politics in Taiwan, London: Routledge. 
Fillingham, Zachary (2016) 'Cross-Strait "status quo" in the balance as Taiwan heads to polls-elections', Eurasia Review, 12 January. Retrieved 30 January 2018 from www.eur asiareview.com/12012016-cross-strait-status-quo-in-the-balance-as-taiwan-heads -to-polls-elections.

Geer, John G. (2006) In Defense of Negativity: Attack Ads in Presidential Campaigns, Chicago: University of Chicago Press.

Hsiao, Hsin-Huang, M. (2016) '2016 Taiwan elections: Significance and implications', Orbis 2o(6): 504-514.

Hsu, Elizabeth and Low, Y.F. (2016) 'Chu vows to "turn Taiwan around”, China Post, 10 January. Retrieved 30 January 2018 from https://chinapost.nownews.com/20160 $110-25645$.

Hsu, Jenny W. (2015) ‘Taiwan's opposition's presidential nominee Tsai Ing-wen says won't change China ties', Wall Street Journal, 15 April. Retrieved 30 April 2015 from www.wsj.com/articles/taiwan-oppositions-presidential-nominee-tsai-ing-wen -says-wont-change-china-ties-142909709o.

Iyengar, Shanto and Kinder, Donald R. (1987) News that Matters: Television and American Opinion, Chicago: University of Chicago Press.

Iyengar, Shanto; Peters, Mark D.; and Kinder, Donald R. (1982) 'Experimental demonstrations of the "not-so-minimal" consequences of television news programs', American Political Science Review 76(4): 848-858.

Iyengar, Shanto and Simon, Adam F. (2000) 'New perspectives and evidence on political communication and campaign effects', Annual Review of Psychology 51: 149-169.

Jacobs, Lawrence R. and Shapiro, Robert Y. (1994) 'Issues, candidate image, and priming: The use of private polls in Kennedy's 1960 presidential campaign', American Political Science Review 88(3): 527-540.

кмт (2015) 'Tsai Ing-wen on 1992 Consensus: Signs of slight shifting of positions. United Daily News editorial: A translation, 29 December 2015', KMT official website, 30 December. Retrieved 30 January 2018 from www1.kmt.org.tw/english/page.aspx? type $=$ article $\&$ mnum $=113 \&$ anum $=17181$.

Lams, Lutgard (2008) 'Media panic or manic: The 2004 Taiwan parliamentary election in the local English-language press', Taiwan International Studies Quarterly 4(4): $145^{-184 .}$

Lams, Lutgard (2012) 'The cross-Strait relations from a linguistic perspective', in Jens Damm and Paul Lim (eds), European Perspectives of Taiwan, Wiesbaden: Springer, 196-214.

Lams, Lutgard and Liao, Li Wen (2011) 'Tracing “Taiwanization” processes in Taiwanese presidential statements in times of cross-Strait rapprochement', Journal of Current Chinese Affairs 40(1): 63-98.

Lippmann, Walter (1922) Public Opinion, New York: Free Press. 
McCombs, Maxwell E. (2004) Setting the Agenda: The Mass Media and Public Opinion, Malden, MA: Blackwell.

McCombs, Maxwell E. and Shaw, Donald L. (1972) 'The agenda-setting function of mass media', Public Opinion Quarterly 36(2): 176-187.

Min, Young (2004) 'Campaign agenda formation: The news media in the Korean congressional election of 2000', Asian Journal of Communication 14(2): 192-204.

Perloff, Richard M. (1998) Political Communication: Politics, Press, and Public in Ameri$c a$, Mahwah, NY: Lawrence Erlbaum.

Price, Vincent and Tewksbury, David (1997) 'News values and public opinion: A theoretical account of media priming and framing', in George A. Barett and Franklin J. Foster (eds), Progress in Communication Sciences: Advances in Persuasion, Vol. 13, Greenwich, ст: Ablex, 173-212.

Rawnsley, Gary (2003) 'An institutional approach to election campaigning in Taiwan', Journal of Contemporary China 12(37): 765-779.

Rawnsley, Gary (2005) 'Democratization and election campaigning in Taiwan: Professionalizing the professionals', in Katrin Voltmer (ed), Mass Media and Political Communication in New Democracies, London: Routledge, 133-151.

Rich, Timothy S. and Sullivan, Jonathan (2016) 'Elections', in Gunter Schubert (ed.), Routledge Handbook of Contemporary Taiwan, London \& New York: Routledge, 119-136.

Rigger, Shelley (2016a) 'Kuomintang agonistes: Party politics in the wake of Taiwan's 2016 elections', Orbis 2o(6): 488-503.

Rigger, Shelley (2016b) 'Party ideology', in Gunter Schubert (ed), Routledge Handbook of Contemporary Taiwan, London \& New York: Routledge, 104-118.

Schafferer, Christian (2006) Election Campaigning in East and South-East Asia, Aldershot: Ashgate.

Scheufele, Dietram A. (200o) 'Agenda-setting, priming, and framing revisited: Another look at cognitive effects of political communication', Mass Communication \& Society 3: 297-316.

Scheufele, Dietram A. and Tewksbury, David (2007) 'Framing, agenda-setting, and priming: The evolution of three media effects models', Journal of Communication $57(1): 9-20$.

Slothuus, Rune and de Vreese, Claes H. (2010) 'Political parties, motivated reasoning, and issue framing effects', Journal of Politics 72(3): 630-645.

Sullivan, Jonathan (2009a) 'Defending negativity? Evidence from presidential campaigns in Taiwan', East Asia 26(4): 305-320.

Sullivan, Jonathan (2009b) 'Campaign advertising in Taiwanese presidential elections', Journal of Contemporary China 18(61): 675-688.

Sullivan, Jonathan (2013) 'Taiwan's 2012 presidential election', Political Studies Review 11: $65^{-74}$. 
Sullivan, Jonathan and Sapir, Eliyahu (2012) 'Nasty or nice? Explaining positive and negative campaigning in Taiwan', The China Journal 67: 149-168.

Sun, Yu-huay (2015) 'President frontrunner disputes China framework for talks', Bloomberg, 28 December. Retrieved 30 January 2018 from www.bloomberg.com/ news/articles/2015-12-28/taiwan-president-frontrunner-disputes-china-framework -for-talks.

Tsai, Ing-wen (2015a) Ing's Clique: The Last Mile to Light up Taiwan (英派：點亮台灣 的這一哩路), Taipei: Yuanshen Press (in Chinese).

Tsai, Ing-wen (2015b) 'Taiwan can build on U.s. ties: A more consistent relationship with China requires open channels of communication, both with China's leadership and the Taiwanese people', The Wall Street Journal, 1 June. Retrieved 30 January 2018 from www.wsj.com/articles/taiwan-can-build-on-u-s-ties-1433176635.

Wan, William (2015) 'Ahead of Taiwan elections, presidential candidate defends outreach to China', The Washington Post, 17 November. Retrieved 30 January 2018 from www.washingtonpost.com/news/worldviews/wp/2015/11/17/taiwans-ruling-party -now-the-underdog-a-q-a-with-its-presidential-candidate $/$ utm_term $=.585 \mathrm{c} 8 \mathrm{f}$ 5oeafo.

Wang, Cheng-chung; Hsieh, Chia-chen; Kuo, Chung-han and Chang, S.C. (2015) 'Chu challenges Tsai to debate on cross-Strait issues', Focus Taiwan, 29 November. Retrieved 4 March 2016 from http://focustaiwan.tw/news/aipl/201511290021.aspx.

Wei, Jennifer (2000) 'An analysis of the metaphorical usage of campaign slogans in the 1996 presidential campaign in Taiwan', Journal of Asian Pacific Communication 10(1): 93-114.

Wu, Yu-shan (2011) 'The evolution of the KMT's stance on the "One China” principle: national identity in flux', in Gunter Schubert and Jens Damm (eds), Taiwanese Identity in the Twenty-First Century, London \& New York: Routledge, 51-71. 